\title{
Analisa Model Struktur Geologi Untuk Menduga Air Tanah Dengan Menggunakan Metode Geolistrik
}

\author{
Azhar Adi Darmawan*, Chairil Saleh, Ernawan Setyono, Andi Saiful Amal \\ Universitas Muhammadiyah Malang \\ Jalan Raya Tlogomas No. 246, Tlogomas, Lowokwaru, Kota Malang, Jawa Timur 65144 \\ *Correspondence email: azharadidfts@umm.ac.id
}

\begin{abstract}
Abstrak. Desa Gondanglegi Kulon berada di Kecamatan Gondanglegi Kabupaten Malang, lokasi penelitian berada dilingkungan wilayah Pondok Pesantren Entrepreneur Muhammadiyah. Dari hasil informasi warga desa sekitar, dijelaskan bahwa sekitar daerah studi tidak diketemukan adanya air tanah dangkal. Hal ini juga diperkuat dengan fakta bahwa tidak adanya sumur dipermukiman warga sekitar Pondok Pesantren Entrepreneur Muhammadiyah, sehingga secara praktis tidak ada warga yang menggunakan sumur sebagai pemenuhan air bersih, sehari-hari warga masih bergantung pada air sungai atau pelayanan PDAM yang relatif mahal dan secara kontinyuitas masih dibawah harapan. Sebagai pusat pendidikan agama, pondok pesantren terus melakukan pengembangan fasilitas pendukung, salah satu fasilitas yang sangat dibutuhkan adalah ketersediaan air bersih. Secara kuantitatif pasokan dari PDAM tidak mencukupi kebutuhan dan biaya operasional yang ditanggung oleh pengelola terlalu tinggi. Pemanfaatan air tanah dalam menjadi solusi yang dapat digunakan untuk memenuhi kebutuhan air bersih di lokasi penelitian. Oleh karena itu diperlukan suatu teknologi untuk mengidentifikasi titik eksplorasinya, teknologi yang digunakan dalam penelitian ini adalah geolistrik resistivitas. Dengan menggunakan metode geolistrik resistivitas, diharapkan dapat mengetahui struktur batuan di lokasi penelitian dan melihat potensi air tanah dalam. Dengan demikian harapan kedepan pihak Pondok Pesantren Entrepreneur Muhammadiyah (PPEM) sudah tidak lagi bergantung pada bahan baku air dari PDAM, sehingga harapannya biaya operasional harian terkait kebutuhan air bersih dapat di minimalisir. Dari hasil analisa dan pembahasan didapatkan 2 (dua) titik rekomendasi pengeboran, namun dengan pertimbangan teknis dan non teknis maka eksplorasi disarankan pada titik 3 dengan potensi sebesar 4,2423 L/det. Dimana pada lokasi ini merupakan susunan litologi batuan yang terdiri dari lapisan top soil, lapisan lempung, lapisan tufa, lapisan lanau pasiran, lapisan pasir dan lapisan kerikil.
\end{abstract}

Kata kunci: Geolistrik; PPEM; Resistivitas; Sumur

Abstract. Gondanglegi Kulon Village is located in Gondanglegi District, Malang Regency, the research location is in the Muhammadiyah Entrepreneur Islamic Boarding School area. From the results of information from local villagers, it was explained that in the study area there was no shallow groundwater found. This is also reinforced by the fact that there are no wells in the settlements of the residents around the Entrepreneur Muhammadiyah Islamic Boarding School, so that practically no residents use wells to fulfill clean water, they still depend on river water or PDAM services which are relatively expensive and continuous. still below expectations. As a center for religious education, Islamic boarding schools continue to develop supporting facilities. One of the most needed facilities is the availability of clean water. Quantitatively, the supply from the PDAM is not sufficient and the operational costs borne by the manager are too high. The use of groundwater is a solution that can be used to meet the needs of clean water at the research location. Therefore we need a technology to identify the point of exploration, the technology used in this research is geoelectric resistivity. By using the resistivity geoelectric method, it is expected to know the rock structure at the research location and see the potential for deep groundwater. Thus, the hope that in the future the Entrepreneur Muhammadiyah Islamic Boarding School (PPEM) will no longer depend on water raw materials from the PDAM, so the hope is that daily operational costs related to clean water needs can be minimized. From the results of the analysis and discussion, 2 (two) points of drilling recommendations were obtained, but with technical and non-technical considerations, exploration was suggested at point 3 with a potential of $4.2423 \mathrm{~L} / \mathrm{sec}$. Where at this location is a rock lithological arrangement consisting of a top soil layer, a clay layer, a tuff layer, a sandy silt layer, a sand layer and a gravel layer.

Keywords: Geoelectric; PPEM; Resistivity; Well

\section{PENDAHULUAN}

Salah satu desa di Kecamatan Gondanglegi terdapat suatu lokasi dimana masyarakatnya sangat menggantungkan kebutuhan air baku hanya dari sungai atau PDAM, yang mana pada desa tersebut juga terdapat Pondok Pesantren. Sebagai pusat pendidikan perlu fasilitas pendukung guna memberikan kenyamanan dalam proses belajar dan mengajar, salah satunya adalah ketersediaan air bersih. Penyediaan air baku yang bersih memiliki arti yang sangat penting dan strategis bagi masyarakat indonesia terutama yang bermukim di wilayah dimana tidak tersedia air bersih atau di wilayah dengan keterbatasan sumber daya air. Dengan kondisi seperti ini mendorong untuk mengembangkan dan menerapkan teknologi pengolahan air yang sederhana, cepat, murah dan berkelanjutan (Indriatmoko, R. H.; Setiadi, I.; \& Yudo, 2020). Pemakaian air bersih yang tinggi digunakan oleh fasilitas asrama siswa dan pengasuh, dapur umum, perkantoran dan tempat ibadah, juga tanaman. Pada saat ini ketersediaan air bersih hanya 
bisa diperoleh dari instalasi PDAM saja, yang tiap tahun secara kuantitatif tidak mencukupi kebutuhan dan biaya yang ditanggung oleh pengelola terlalu tinggi. Pemanfaatan air tanah menjadi solusi yang akan digunakan untuk memenuhi kebutuhan air bersih di lokasi ponpes. Akan tetapi berdasarkan hasil wawancara dengan warga sekitar kondisi air tanah di lokasi Ponpes sulit untuk ditemukan, sehingga diperlukan suatu teknologi untuk mengidentifikasinya. Teknologi yang bisa digunakan untuk mengidentifikasi potensi air tanah adalah metode geolistrik resistivitas. Pada penelitian ini tidak membahas terkait kualitas dari potensi air yang didapatkan, karena hal tersebut masih dibutuhkan penelitian lanjutan dengan metode yang lain pula (Simaremare, 2015). Dengan penelitian ini dapat diketahui fenomena apa yang mendasari hal diatas terjadi berbasis ilmu pengetahuan, sehingga dapat dicari alternatif solusinya. Secara konsep kelangkaan air tanah dapat dipengaruhi oleh beberapa faktor, misalnya jenis batuan, jenis tanah, topografi, vegetasi, dan beberapa hal lain. Dalam penelitian ini difokuskan pada pengamatan struktur geologi atau batuan yang menyusun lapisan tanah dilokasi studi, sehingga dapat dilihat potensi ketersediaan air yang ada dilapisan geologi dimaksud.

\section{METODE}

Metode penelitian yang digunakan dalam penelitian ini adalah metode survei yang meliputi pengumpulan data primer dan data sekunder. Pengumpulan data primer dilakukan dengan melakukan kegiatan wawancara langsung dengan masyarakat sekitar pondok dan pengukuran geolistrik pada bulan Mei 2020 yang dilaksanakan didalam lingkungan Pondok Pesantren Entrepreneur Muhammadiyah (PPEM) Gondanglegi.

Alat yang digunakan untuk memperoleh data dalam penelitian ini antara lain alat geolistrik untuk mengukur resistivitas batuan dilokasi penelitian dan dibatasi pengukuran hingga kedalaman $150 \mathrm{~m}$, dan sistem penentuan titik analisa posisi global (GPS) untuk menentukan koordinat titik pengukuran geolistrik. Metode geolistrik merupakan salah satu dari kelompok metode geofisika yang digunakan untuk mempelajari keadaan bawah permukaan dengan cara mempelajari sifat aliran listrik di dalam batuan di bawah permukaan bumi (Usman et al., 2017). Data sekunder yang dibutuhkan dalam penelitian ini antara lain : Peta Geologi Lembar Turen diterbitkan oleh Geological Research and Pusat Pengembangan tahun 1992 dan Peta Hidrogeologi Kediri Skala 1: 250.000 diterbitkan oleh Direktorat Geologi Lingkungan pada tahun 1984. Data yang diperoleh dari pengukuran geolistrik konfigurasi Schlumberger adalah: tahanan $\mathrm{R}$ dalam satuan $\mathrm{Ohm}$ dan Arus yang diinjeksikan I dalam satuan Ampere, sedangkan beda potensial V dalam satuan Volt dihitung berdasarkan perkalian antara I dan R (Rosyid, 2019). Arus yang diinjeksikan selama dalam pengambilan data adalah arus searah terkomutasi (DC terkomutasi) untuk menghindari terjadinya polarisasi. Dan untuk mengukur beda potensialnya menggunakan resistivitimeter. Alat ini sangat peka dengan bahan yang bersifat konduktif, oleh karena itu dalam aplikasinya harus benar-benar kering, jika medan basah maka massa jenis air dan tanah menyatu sehingga bernilai sama. Data geolistrik hasil pengukuran yang menggambarkan kondisi bawah permukaan digunakan sebagai patokan untuk menentukan titik pemboran pada daerah pengambilan data. Nilai resistivitas dan panjang bentangan dari metode geolistrik memberikan gambaran keadaan bawah permukaan yang berupa lapisan-lapisan batuan berpori yang mengandung mineral. Kandungan air, fluida atau mineral lain didalam pori-pori batuan mengakibatkan adanya perubahan nilai resistivitas batuan sebenarnya. Koefisian kelulusan air (Coeficient of Permeability / Hydraulic Conductivity) adalah kemampuan untuk meluluskan air di dalam rongga-rongga batuan tanpa mengubah sifat-sifat airnya.

Koefisien kelulusan air terdiri dari koefisian kelulusan air di lapangan (Kf) dan koefisian kelulusan air di laboratorium atau standart (Ks).

$$
K=\frac{Q}{A x d h / d l}=\frac{L^{3} / T}{L^{2} x L / L}=\frac{L}{T}=\frac{m}{\text { hari }}
$$

Airtanah dalam keadaan sebenarnya gerakannya tidak berubah. Gerakan tersebut sesuai dengan prinsip prinsip hidrolika. Airtanah yang mengalir melewati lapisan akuifer dasar hukum yang berlaku adalah hukum Darcy dan persamaan Kontinuitas. Dimana Hukum Darcy adalah $\mathrm{Q}=\mathrm{K}$. i. A (Bisri, 2008).

\section{HASIL DAN PEMBAHASAN}

Air Tanah adalah air yang terdapat di dalam lapisan tanah atau batuan di bawah permukaan tanah (Pedoman Penetapan Zona Konservasi Air Tanah, 2018).

Berdasarkan hasil perhitungan dan interpretasi data lapangan geolistrik, diperoleh parameter-parameter dari jenis batuan berdasarkan tanahan jenis pada kedalaman yang bervariasi. Maka langkah selanjutnya adalah mengkorelasikan besaran tahanan jenis batuan dengan jenis batuan yang ada di daerah pengukuran dengan membandingkan tabel nilai tahanan jenis batuan yang ada dengan nilai tahanan jenis batuan berdasarkan hasil penelitian ahli geofisika terdahulu. Dalam pengambilan data menggunakan konfigurasi Schlumberger dengan teknik sounding, sehingga referensi sepanjang lintasan dapat dipergunakan. Berbeda dengan metode wenner, data hasil pengukuran terpusat pada titik tengah lintasan pengukuran (Nashrullah et al., 2018).

Pengukuran geolistrik dilakukan di area lingkungan Pondok Pesantren, dari hasil penelusuran awal dengan menggunakan pendulum awalnya 
Azhar Adi Darmawan, Chairil Saleh, Ernawan Setyono dan Andi Saiful Amal, Analisa Model Struktur Geologi Untuk Menduga Air Tanah Dengan Menggunakan Metode Geolistrik

ditentukan 4 titik yang akan dilakukan pengukuran resistivitas seperti pada Gambar 1. Namun dengan pertimbangan keterbatasan lokasi dan hasil pengamatan dengan menggunakan pendulum yang peneliti perkirakan titik 1 dengan 4 dan 2 dengan 3 adalah satu alur aliran, maka titik pengamatan dilakukan pada titik 1 dan 3. Konfigurasi elektroda menggunakan konfigurasi Schlumberger dengan bentang elektroda arus (C1C2) sepanjang 300 meter. Dengan jarak bentang sepanjang 300 meter maka akan didapatkan kedalaman pendugaan geolistrik (C1C2/2) sedalam 150 meter (Agustina et al., 2018).

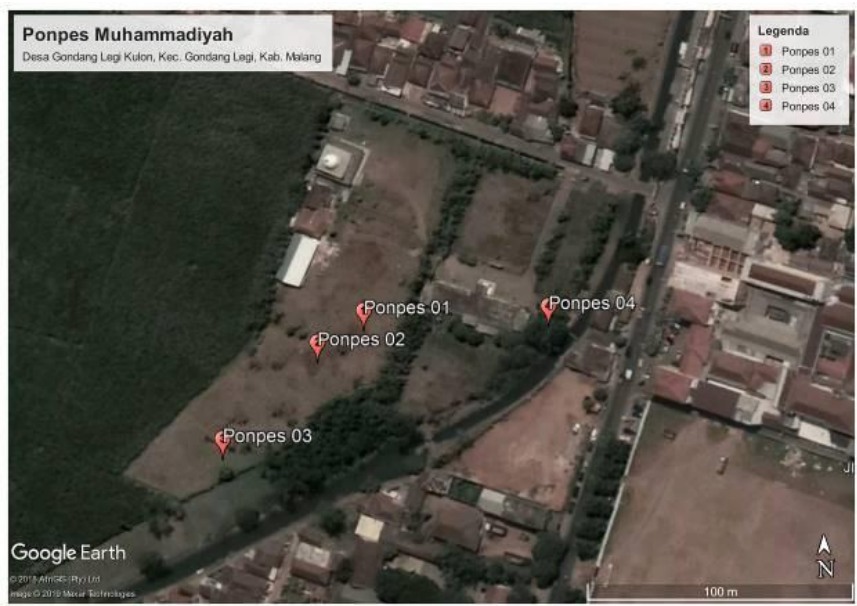

Gambar 1. Lokasi penelitian dan titik pengumpulan data awal
(Sumber: Pengukuran/Analisa Lapangan)

Posisi rencana pengamatan dilakukan dengan membuat daftar inventarisir yang memuat data terkait titik koordinat dan ketinggian (elevasi) permukaan bumi (Permana, 2019). Hasil inventarisasi rencana pengamatan titik dilakukan dengan menggunakan GPS dan dapat dilihat dalam Tabel 1 berikut.

Tabel 1. Data koordinat titik - titik geolistrik

\begin{tabular}{ccccc}
\hline \multirow{2}{*}{ No } & \multirow{2}{*}{ Nama Titik } & \multicolumn{2}{c}{ Koordinat } & Elevasi \\
\cline { 3 - 5 } & & $\mathbf{S}$ & $\mathbf{E}$ & Mdpl \\
$\mathbf{1}$ & Ponpes 01 & $08^{\circ} 10^{\prime} 13,0^{\prime \prime}$ & $112^{\circ} 38^{\prime} 20,0^{\prime \prime}$ & 368 \\
$\mathbf{2}$ & Ponpes 02 & $08^{\circ} 10^{\prime} 13,4^{\prime \prime}$ & $112^{\circ} 38^{\prime} 19,4^{\prime \prime}$ & 374 \\
$\mathbf{3}$ & Ponpes 03 & $08^{\circ} 10^{\prime} 14,6^{\prime \prime}$ & $112^{\circ} 38^{\prime} 18,2^{\prime \prime}$ & 367 \\
$\mathbf{4}$ & Ponpes 04 & $08^{\circ} 10^{\prime} 13,0^{\prime \prime}$ & $112^{\circ} 38^{\prime} 22,4^{\prime \prime}$ & 373 \\
\hline
\end{tabular}

Sumber: pengukuran/analisa lapangan

\section{Titik Geolistrik 1 (Ponpes 01)}

Titik geolistrik 01 terletak di bagian tengah atau samping kiri bangunan dapur umum (pin merah no 3 pada Gambar 1). Bentang elektroda arus dan potensial memanjang lurus ke arah utara dan selatan dari lokasi pengukuran. Panjang bentang elektroda arus (C1C2) hingga mencapai $220 \mathrm{~m}$, sedangkan bentang elektroda potensial (P1P2) mencapai 100 meter. Hasil pengamatan perlakuan pada lokasi titik 1 dapat dilihat dalam Gambar 2 dan litologi batuan secara jelas dapat dilihat pada Tabel 2 berikut.

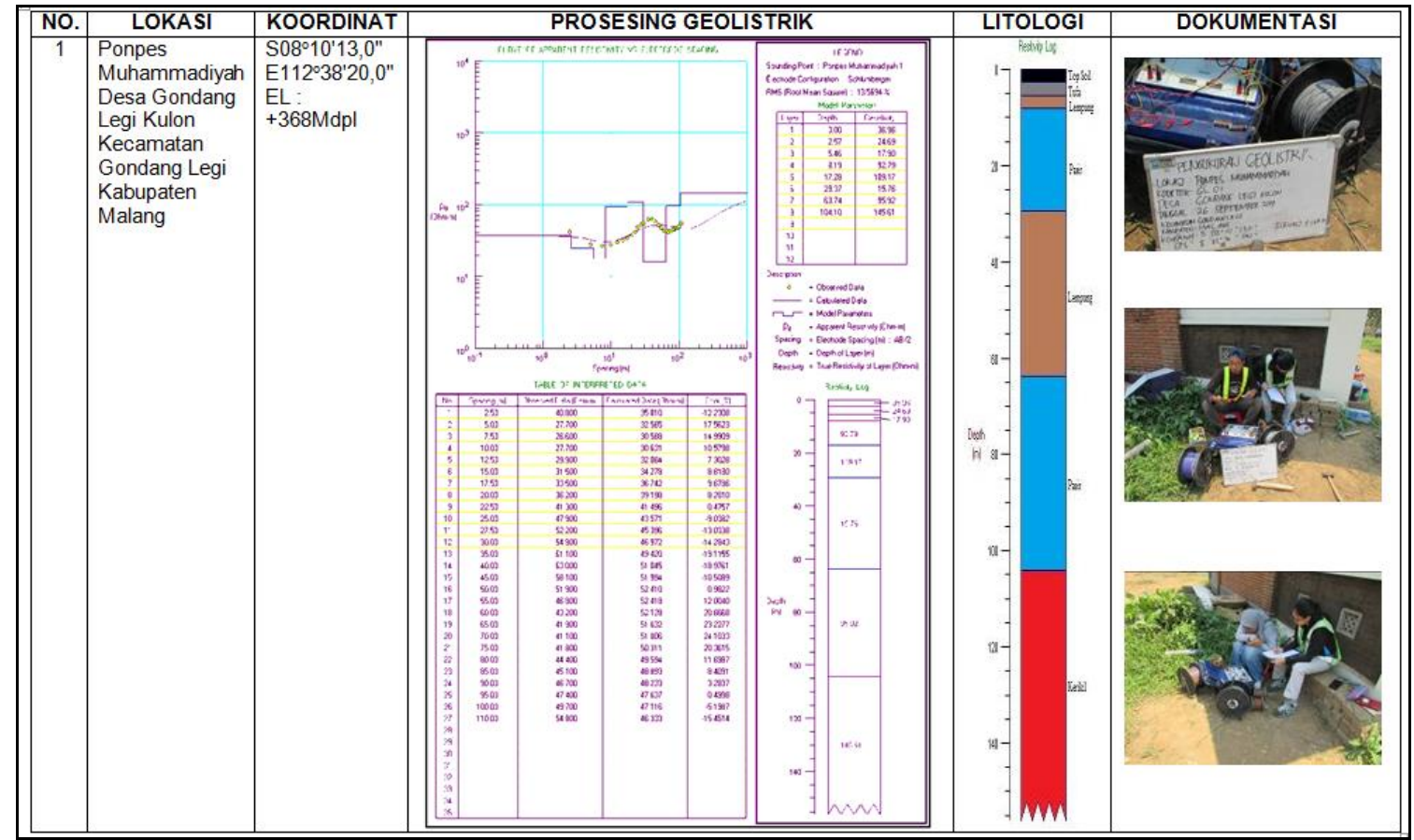

Gambar 2. Hasil pengamatan lokasi titik 01

(Sumber: pengukuran/analisa lapangan) 
Tabel 2. Data pengamatan

\begin{tabular}{ccc}
\hline \multicolumn{3}{c}{ Titik Geolistrik 01 } \\
\hline Kedalaman $(\mathbf{m})$ & $\begin{array}{c}\text { Resistivitas } \\
(\mathbf{\Omega m})\end{array}$ & Jenis batuan \\
$\mathbf{0}-\mathbf{2 , 5 7}$ & 36,96 & Top Soil/Tanah \\
Permukaan \\
$\mathbf{2 , 5 7}-\mathbf{5 , 4 6}$ & 24,69 & Tufa \\
$\mathbf{5 , 4 6}-\mathbf{8 , 1 9}$ & 17,90 & Lempung \\
$\mathbf{8 , 1 9}-\mathbf{2 9 , 3 7}$ & $92,79-109,17$ & Pasir \\
$\mathbf{2 9 , 3 7}-\mathbf{6 3 , 7 4}$ & 15,76 & Tufa \\
$\mathbf{6 3 , 7 4}-\mathbf{1 0 4 , 1 0}$ & 95,92 & Pasir \\
$\mathbf{1 0 4 , 1 0}-\mathbf{1 1 0}$ & 145,61 & Kerikil/batu apung \\
\hline
\end{tabular}

Sumber: pengukuran/analisa lapangan

Kesesuaian litologi batuan di titik survey geolistrik 01 terhadap lapisan geologi lokasi pengukuran yang berada pada lembar endapan tufa gunung api (Qptm) dapat dikatakan sesuai, dengan batuan - batuan penyusunnya antara lain: lapisan top soil, lapisan lempung, lapisan tufa, lapisan pasir dan lapisan kerikil. Lapisan permukaan hingga kedalaman 8 meter batuan didominasi lapisan lempung hingga tufa. Sedangkan pada kedalaman 8 meter hingga 104 meter lapisan batuan berseling antara lapisan pasir dan lapisan tufa, sedangkan kedalaman 104 meter hingga 110 meter sebagai batas kedalaman maksimal titik geolistrik 01 berupa lapisan kerikil atau batu apung. Lapisan batuan yang teridentifikasi mengandung air tanah terdapat pada kedalaman 60 meter. Berdasarkan Gambar 3 titik geolistrik 01 memiliki potensi air tanah pada lapisan akuifernya, hal ini ditunjukkan adanya anomali penurunan nilai resistivitas dari batuan yang bersifat akuifer. Air tanah teridentifikasi dengan adanya pembacaan anomali nilai resistivitas lapisan akuifer yang berupa pasir, mulai pada kedalaman 63,74 meter hingga 104,10 meter, hal ini mengindikasikan bahwa lapisan akuifer pada kedalaman tersebut sangat berpotensi menghasilkan debit air tanah yang produktif. Hasil analisa pengamatan resistivity dapat dilihat dalam Gambar 3 dan nilai transmisivitas dapat dilihat pada Tabel 3 berikut.

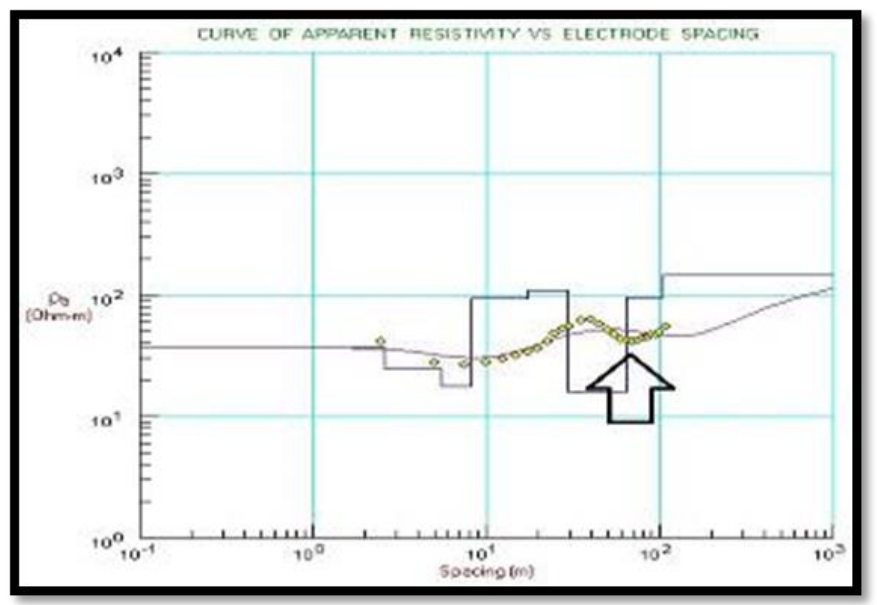

Gambar 3. Hasil analisa resistivity lokasi titik 01 (Sumber: analisa data)

Tabel 3. Transmisivitas dan Debit Potensial Titik Geolistrik 01

\begin{tabular}{|c|c|c|c|c|c|c|}
\hline \multicolumn{3}{|c|}{ Titik Geolistrik 01} & \multirow{2}{*}{$\begin{array}{c}\text { Transmisivitas } \\
\left(\mathrm{m}^{2} / \text { det }\right)\end{array}$} & \multicolumn{2}{|c|}{ Debit Potensial } & \multirow[b]{2}{*}{ Keterangan } \\
\hline Kedalaman (m) & Resistivitas ( $\Omega \mathrm{m})$ & Jenis batuan & & $Q\left(\mathrm{~m}^{3} / \mathrm{det}\right)$ & $\begin{array}{c}\mathbf{Q} \\
\text { (L/det) }\end{array}$ & \\
\hline $0-2,57$ & 36,96 & $\begin{array}{l}\text { Top Soil/Tanah } \\
\text { Permukaan }\end{array}$ & & & & \\
\hline $2,57-5,46$ & 24,69 & Tufa & & & & \\
\hline $5,46-8,19$ & 17,90 & Lempung & & & & \\
\hline $8,19-29,37$ & $92,79-109,17$ & Pasir & & & & \\
\hline $29,37-63,74$ & 15,76 & Tufa & & & & \\
\hline $63,74-104,10$ & 95,92 & Pasir & 0,0052 & 0,0013 & 1,2557 & Air tanah \\
\hline $104,10-110$ & 145,61 & Kerikil/batu apung & & & & \\
\hline \multicolumn{2}{|c|}{ Debit Potensial Total } & & & 0,0013 & 1,2557 & \\
\hline
\end{tabular}

Sumber: pengukuran/analisa lapangan

Berdasarkan hasil pengolahan data geolistrik bahwa muka air tanah di titik geolistrik 01 sangat dalam hingga kedalaman lebih dari 60 meter, hal ini sesuai dengan hasil wawancara dengan warga tetapi berbeda dengan keterangan dari peta hidrologi. Berdasarkan hasil perhitungan terhadap lapisan akuifer yang telah teridentifikasi dengan pengukuran geolistrik didapatkan nilai debit potensial di titik geolistrik 01. Perhitungan potensi debit dengan menggunakan rumus Darcy dengan parameter - parameter yang diperhitungkan antara lain: tebal lapisan akuifer, koefisien permeabilitas $(\mathrm{K}=$ $0,0005208 \mathrm{~m} / \mathrm{det})$, jari - jari pipa konstruksi $(\mathrm{r}=0,0762$ $\mathrm{m})$, kemiringan akuifer $(\mathrm{i}=1)$, dan luas penampang akuifer (A). Dari parameter - parameter tersebut didapatkan nilai transmisivitas $\left(\mathrm{m}^{2} / \mathrm{det}\right)$ dan potensial debit (L/det) tiap - tiap lapisan akuifer. Berdasarkan perhitungan (Tabel 3), titik geolistrik 01 memiliki potensi debit lapisan akuifer sebesar $1,2557 \mathrm{l} / \mathrm{det} \approx 1,3$ $1 / \mathrm{dt}$.

\section{Titik Geolistrik 3 (Ponpes 03)}

Titik geolistrik 03 terletak di bagian belakang sisi selatan ponpes yang berbatasan langsung dengan saluran irigasi dan tanah milik warga setempat (pin merah no 3 
Azhar Adi Darmawan, Chairil Saleh, Ernawan Setyono dan Andi Saiful Amal, Analisa Model Struktur Geologi Untuk Menduga Air Tanah Dengan Menggunakan Metode Geolistrik

Gambar 1). Panjang bentang elektroda arus sepanjang $300 \mathrm{~m}$ dan panjang bentang elektroda potensial sepanjang 100 meter, ke arah selatan dan ke arah utara lokasi pengukuran. Hasil pengamatan perlakuan pada lokasi titik 03 dapat dilihat dalam Gambar 4 dan litologi batuan secara jelas dapat dilihat pada Tabel 4 berikut.

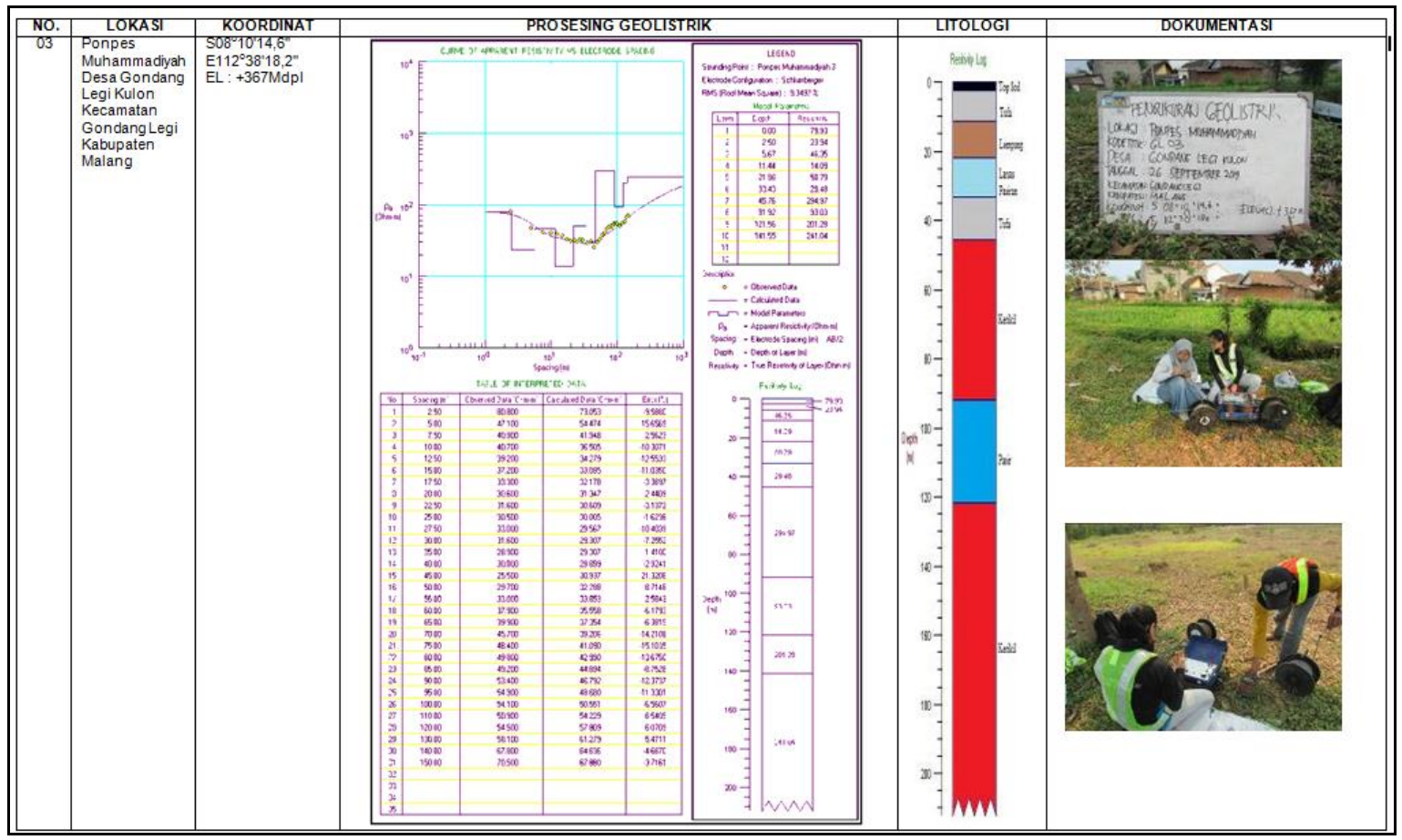

(Sumber: pengukuran/analisa lapangan)

Tabel 4. Data pengamatan

\begin{tabular}{|c|c|c|}
\hline \multicolumn{3}{|c|}{ Titik Geolistrik 03} \\
\hline $\begin{array}{c}\text { Kedalaman } \\
\text { (m) }\end{array}$ & $\begin{array}{c}\text { Resistivitas } \\
(\Omega \mathrm{m})\end{array}$ & Jenis batuan \\
\hline $0-2,50$ & 79,93 & $\begin{array}{l}\text { Top Soil/Tanah } \\
\text { Permukaan }\end{array}$ \\
\hline $2,50-11,44$ & $23,94-46,35$ & Tufa \\
\hline $11,44-21,86$ & 14,09 & Lempung \\
\hline $21,86-33,43$ & 50,79 & Lanau pasiran \\
\hline $33,43-45,76$ & 29,48 & Tufa \\
\hline $45,76-91,92$ & 294,97 & Kerikil \\
\hline $91,92-121,56$ & 93,03 & Pasir \\
\hline $121,56-150$ & $201,28-241,04$ & Kerikil \\
\hline
\end{tabular}

Sumber: pengukuran/analisa lapangan

Kesesuaian litologi batuan di titik survey geolistrik 03 terhadap lapisan geologi lokasi pengukuran yang berada pada lembar endapan tuff gunungapi (Qptm) dapat dikatakan sesuai dengan batuan - batuan penyusunnya antara lain: lapisan top soil, lapisan lempung, lapisan tufa, lapisan lanau pasiran, lapisan pasir dan lapisan kerikil. Susunan batuan permukaan hingga kedalaman 45,76 meter berupa dominansi lapisan batuan berukuran halus hingga sedang yaitu lapisan lempung hingga lanau pasiran. Dikedalaman 45,76 meter hingga 150 meter dominansi lapisan kerikil yang tersisipi lapisan pasir. Lapisan batuan yang teridentifikasi mengandung air tanah di titik geolistrik 03 adalah lapisan tufa di kedalaman 33,43 - 45,76 meter dan lapisan pasir di kedalaman 91,92 - 121,56 meter.
Berdasarkan Gambar 5 titik geolistrik 03 memiliki potensi air tanah pada lapisan akuifernya, hal ini ditunjukkan adanya anomali penurunan nilai resistivitas dari batuan yang bersifat akuifer. Lapisan air tanah dangkal teridentifikasi di kedalaman antara 33,43 45,76 meter, lapisan air tanah berikutnya teridentifikasi di lapisan akuifer mulai kedalaman 91,92 - 121,56 meter. Hal ini mengindikasikan bahwa lapisan akuifer pada kedalaman tersebut sangat berpotensi menghasilkan debit air tanah yang produktif. Hasil analisa pengamatan resistivity dapat dilihat dalam Gambar 5 dan nilai transmisivitas dapat dilihat pada Tabel 5 berikut.

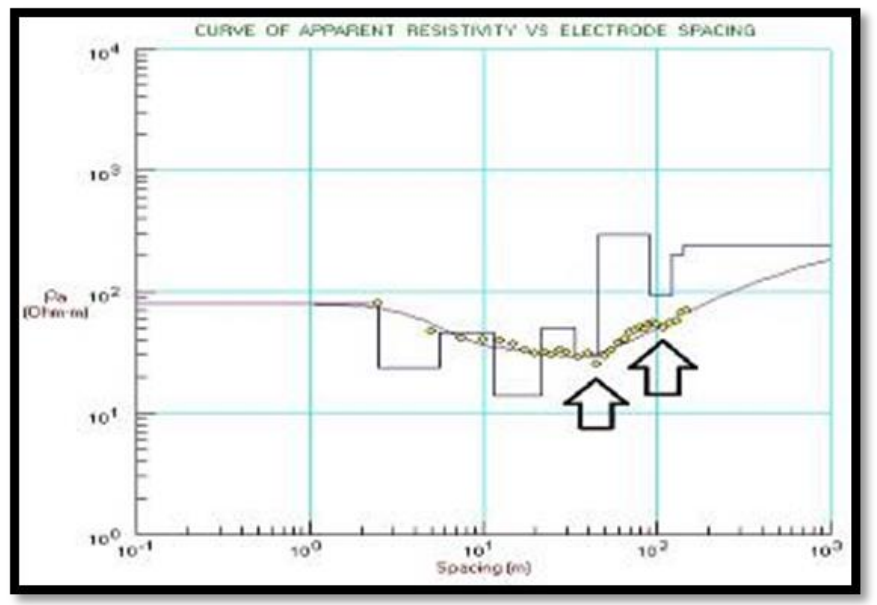

Gambar 5. Hasil analisa resistivity lokasi titik 03 (Sumber: analisa data) 
Azhar Adi Darmawan, Chairil Saleh, Ernawan Setyono dan Andi Saiful Amal, Analisa Model Struktur Geologi Untuk Menduga Air Tanah Dengan Menggunakan Metode Geolistrik

Tabel 5. Transmisivitas dan Debit Potensial Titik Geolistrik 03

\begin{tabular}{|c|c|c|c|c|c|c|}
\hline \multicolumn{3}{|c|}{ Titik geolistrik 03} & \multirow{2}{*}{$\begin{array}{c}\text { Transmisivitas } \\
\left(\mathrm{m}^{2} / \mathrm{det}\right)\end{array}$} & \multicolumn{2}{|c|}{ Debit Potensial } & \multirow[b]{2}{*}{ Keterangan } \\
\hline $\begin{array}{c}\text { Kedalaman } \\
(\mathrm{m})\end{array}$ & Resistivitas $(\mathbf{\Omega m})$ & Jenis batuan & & $\begin{array}{c}\mathbf{Q} \\
\left(\mathbf{m}^{3} / \mathbf{d t}\right)\end{array}$ & $\begin{array}{c}\mathbf{Q} \\
\text { (L/dett) }\end{array}$ & \\
\hline $\mathbf{0}-\mathbf{2 , 5 0}$ & 79,93 & $\begin{array}{c}\text { Top Soil/Tanah } \\
\text { Permukaan }\end{array}$ & & & & \\
\hline $2,50-11,44$ & $23,94-46,35$ & Tufa & & & & \\
\hline $11,44-21,86$ & 14,09 & Lempung & & & & \\
\hline $21,86-33,43$ & 50,79 & Lanau pasiran & & & & \\
\hline $33,43-45,76$ & 29,48 & Tufa & 0,0017 & 0,0015 & 1,5460 & Air tanah \\
\hline $45,76-91,92$ & 294,97 & Kerikil & & & & \\
\hline $91,92-121,56$ & 93,03 & Pasir & 0,0112 & 0,0027 & 2,6963 & Air tanah \\
\hline $121,56-150$ & $201,28-241,04$ & Kerikil & & & & \\
\hline \multicolumn{2}{|c|}{ Debit Potensial Total } & & & 0,0042 & 4,2423 & \\
\hline
\end{tabular}

Sumber: pengukuran/analisa lapangan

Berdasarkan hasil pengolahan data geolistrik bahwa muka air tanah dangkal di titik geolistrik 03 sangat dalam hingga kedalaman lebih dari 33 meter, hal ini sesuai dengan hasil wawancara dengan warga tetapi berbeda dengan keterangan dari peta hidrologi. Berdasarkan hasil perhitungan terhadap lapisan akuifer yang telah teridentifikasi dengan pengukuran geolistrik didapatkan nilai debit potensial di titik geolistrik 03 . Perhitungan potensi debit menggunakan rumus Darcy dan cara yang sama seperti lokasi pertama. Berdasarkan perhitungan (Tabel 5), titik geolistrik 03 memiliki potensi debit lapisan akuifer 1 sebesar 1,5460 L/det dan lapisan akuifer 2 sebesar 2,6963 L/det. Apabila masing masing lapisan akuifer dipasang screen maka akan diperoleh total potensial debit sebesar 4,2423 L/det $\approx 4,2$ L/dt.

\section{SIMPULAN}

Berdasarkan hasil pembahasan dan analisa data, maka dapat disimpulkan sebagai hasil dari penelitian ini, yaitu lokasi titik yang diduga mempunyai potensi paling besar mengandung air tanah adalah titik 03 dengan kedalaman maksimal kurang lebih 120 meter. Pada titik lokasi 01 potensi air tanah pada sulit didapatkan atau memiliki potensi yang jauh lebih kecil, karena memiliki nilai transmisivitas dengan nilai kecil dan hanya ada pada 1 lapisan jenis batuan.

\section{DAFTAR PUSTAKA}

Agustina, R. D., Pazha, H., \& Sugilar, H. (2018). Identification of subsurface basement rock using geoelectrical resistivity method in development area (campus 2 UIN Sunan Gunung Djati Bandung). IOP Conference Series: Materials Science and Engineering, 434(1), 0-6. https://doi.org/10.1088/1757-899X/434/1/012289

Bisri, M. (2008). Air Tanah. Tirta Media.

Pedoman Penetapan Zona Konservasi Air Tanah, Pub. L. No. Nomor 31 Tahun 2018, ESDM, Kementerian (2018).
Indriatmoko, R. H.; Setiadi, I.; \& Yudo, S. (2020). Diseminasi Teknologi Pengolahan Air Siap Diminum Bagi Masyarakat Studi Kasus: Diseminasi di Pesantren Syubbanul Yaum Tenajar Kertasemaya, Indramayu Jawa Barat. Jurnal Rekayasa Lingkungan, 13(1). https://doi.org/https://dx.doi.org/10.29122/jrl.v13i 1.4291

Nashrullah, A., Widodo, S., Bakri, H., \& Prasetyawati Umar, E. (2018). Pendugaan Potensi Air Tanah Menggunakan Geolistrik Tahanan Jenis Daerah Pesisir Kabupaten Luwu Provinsi Sulawesi Selatan. Jurnal Geomine, 6(2), 60-64. https://doi.org/10.33536/jg.v6i2.210

Permana, P. (2019). Analisis Kualitas Dan Pemanfaatan Air Tanah Di Kecamatan Kota Barat Gorontalo. Jurnal Geomine, 7(1), 13. https://doi.org/10.33536/jg.v7i1.336

Rosyid, M. I. . \& D. (2019). Pemanfaatan metode geolistrik resistivitas untuk mengetahui struktur geologi sumber air panas di daerah songgoriti kota batu. Fisiska FMIPA UM, 1, 1-9. https://www.mendeley.com/catalogue/e8c9ac752023-3640-bc02-6d9f4c4aafca/\#abstract-title

Simaremare, S. (2015). Analisis Aliran Air Tanah Satu Dimensi (Kajian Laboratorium). Teknik Sipil Dan Lingkungan, $\quad 3(1), \quad$ 783-794. https://www.mendeley.com/catalogue/b96346d58e54-370a-8fee-59890fb010fa/

Usman, B., Manrulu, R. H., Nurfalaq, A., \& Rohayu, E. (2017). Identifikasi Akuifer Air Tanah Kota Palopo Menggunakan Metode Geolistrik Tahanan Jenis Konfigurasi Schlumberger. Jurnal Fisika FLUX, 14(2), 